\title{
PENGEMBANGAN MODEL PEMBELAJARAN COLLABORATIVE PROBLEM BASED LEARNING DALAM PEMBELAJARAN KIMIA DI PERGURUAN TINGGI
}

\author{
Rusly Hidayah ${ }^{1}$, Fauziatul Fajaroh ${ }^{2}$, Romita Erika Narestifuri ${ }^{1}$ \\ ${ }^{1}$ Universitas Negeri Surabaya, Indonesia \\ ${ }^{2}$ Universitas Negeri Malang, Indonesia \\ *Corresponding Address: ruslyhidayah@unesa.ac.id
}

Naskah diterima: 10Agustus 2021| Disetujui: 3 September 2021 | Diterbitkan: 5 September 2021

\begin{abstract}
Learning activities, especially in chemistry lessons, are challenging and quite complicated learning activities. In addition, the provision of information such as teaching materials from lecturers needs to be reduced so that students can find, process, and use the learning resources they get. One of the learning models that can be used is the Collaborative Learning (CL) and Problem Based Learning (PBL) models. This model provides an opportunity to develop the social skills needed. Therefore, the researcher took the initiative to conduct a literature study to determine the effect of applying CL and PBL on chemistry learning. This research was conducted using a systematic analysis approach through several references in the form of journals published in the last 10 years, articles relevant to the research topic. Based on research results from several journals, it can be concluded that the CL model combined with PBL allows lecturers and students to share information more effectively and efficiently.
\end{abstract}

Keywords: chemistry; CL; PBL; learning outcomes.

\begin{abstract}
Abstrak: Kegiatan pembelajaran khususnya pada pelajaran kimia merupakan kegiatan pembelajaran yang menantang dan cukup rumit. Selain itu, pemberian informasi seperti bahan ajar dari dosen perlu dikurangi agar mahasiswa dapat menemukan, mengolah, dan menggunakan sumber belajar yang diperolehnya. Salah satu model pembelajaran yang dapat digunakan adalah model collaborative learning (CL) dan problem based learning (PBL). Model ini memberikan kesempatan untuk mengembangkan keterampilan sosial yang dibutuhkan. Oleh karena itu, peneliti berinisiatif untuk melakukan studi literatur untuk mengetahui pengaruh penerapan CL dan PBL terhadap pembelajaran kimia. Penelitian ini dilakukan dengan menggunakan pendekatan analisis sistematis melalui beberapa referensi berupa jurnal yang diterbitkan dalam 10 tahun terakhir, artikel yang relevan dengan topik penelitian. Berdasarkan hasil penelitian dari beberapa jurnal dapat disimpulkan bahwa model CL yang dipadukan dengan PBL memungkinkan dosen dan mahasiswa untuk saling berbagi informasi secara lebih efektif dan efisien.
\end{abstract}

KATA KUNCI: KIMIA; CL; PBL; HASIL BELAJAR

2656-9779 (C) 2020 The Author(s).

Published by Lembaga Penerbitan dan Publikasi Ilmiah Program Pascasarjana IAI Sunan Giri Ponorogo. This is an open access article under the CC BY-SA 4.0 license. DOI: 10.37680/qalamuna.v13i2.1016 


\section{PENDAHULUAN}

Kegiatan belajar mengajar dirancang untuk mencapai tiga aspek, diantaranya kognitif, afektif, dan psikomotorik. Mahasiswa diharapkan tidak hanya mempelajari materi, tetapi juga keterampilan yang relevan dengan topik pembelajaran. Ketiga aspek tersebut harus diterapkan dalam setiap kegiatan belajar untuk menciptakan keseimbangan kompetensi kognitif, afektif, dan psikomotorik mahasiswa. Selain upaya untuk memenuhi ketiga aspek kompetensi ini, kegiatan evaluasi disetiap akhir pembelajaran ikut berpengaruh terhadap hasil belajar. Untuk memastikan tercapainya target pemahaman dengan kondisi yang sebenarnya setelah proses pembelajaran, maka setidaknya penilaian mendasar dari aspek kognitif seperti konsep pemahaman dan penguasaan materi di luar kepala harus dapat dilakukan.

Pencapaian prestasi yang baik dihasilkan dari proses belajar yang dilakukan dengan baik. Pada umumnya, kegiatan belajar mengajar diawali dengan pemberian masalah, sehingga dapat meningkatkan kemandirian mahasiswa untuk menemukan solusi secara mandiri sekaligus menanamkan pemahaman yang lebih baik. Mengidentifikasi masalah dapat menjadi kesempatan yang baik untuk memotivasi pemecahan masalah oleh mahasiswa yang mengacu pada rasa ingin tahu mereka yang tinggi (Handayani, et al., 2013). Saat ini, kegiatan pembelajaran berorientasi pada mahasiswa menjadi studi penelitian penting di kalangan pendidik. Partisipasi aktif mahasiswa akan menghasilkan pengetahuan mendasar dari diri sendiri. Namun, pada kondisi saat ini untuk meningkatkan potensi mahasiswa belum sepenuhnya terfasilitasi dengan baik. Kebanyakan mahasiswa masih bergantung pada pembekalan pengetahuan dan informasi dari dosen serta belum dapat memanfaatkan sumber belajar secara optimal untuk menanamkan kemandirian belajar dan rasa percaya diri.

Kegiatan pembelajaran terutama pada topik sains seperti kimia merupakan proses yang menantang dan cukup rumit. Hal ini berkaitan dengan anggapan bahwa ilmu pengetahuan alam seperti mata kuliah tersebut dirasa merupakan mata pelajaran yang cukup sulit. Selain itu, dosen harus menyadari bahwa pembelajaran sains seringkali melibatkan pengetahuan dasar yang sebelumnya telah dibawa oleh mahasiswa. Pengetahuan dasar ini dapat membantu mahasiswa memahami sains, namun juga berpotensi menyebabkan miskonsepsi apabila pemahaman yang ada tidak selaras dengan teori dasarnya. Terlepas dari berbagai tantangan yang telah disebutkan, penguasaan cabang ilmu ini termasuk faktor penting dalam pembangunan nasional di masa depan karena berhubungan dengan bermacam aspek. Oleh karena itu, proses pembelajaran mata kuliah kimia seharusnya dapat dilakukan dengan model yang sesuai dengan tuntutan output pembelajaran dari kurikulum yang digunakan pada saat ini dengan tetap menjamin pemahaman materi pada mahasiswa. 
Salah satu model untuk membantu mempermudah penguasaan materi bagi mahasiswa ialah Collaborative learning (CL). Pembelajaran kolaboratif atau collaborative learning dapat didefinisikan sebagai seperangkat strategi belajar mengajar yang menerapkan kolaborasi antar mahasiswa dalam kelompok kecil (dua hingga lima mahasiswa) untuk mengoptimalkan pembelajaran mereka sendiri serta satu sama lain. CL dapat mendorong peningkatan hasil pendidikan akademik maupun kualitas interaksi sosial mahasiswa. Model ini juga berguna untuk meningkatkan sikap Selfregulated dari mahasiswa.

Self-regulated learning merupakan sikap yang diperoleh mahasiswa sebagai hasil belajar dan tanggung jawab dalam memecahkan masalah (Kalenda, 2016). Self-regulated learning dapat dikembangkan melalui keterampilan pada proses pembelajaran sains karena mahasiswa dapat melakukan penyelidikan ilmiah untuk memecahkan masalah melalui berbagai sumber belajar serta berperan aktif dalam proses pembelajaran. Di samping itu, pemberian informasi bahan ajar dari dosen dapat lebih dikurangi agar peserta didik dapat mencari, mengolah, dan menggunakan sumber belajar yang diperolehnya (Susilowati, 2013). Model pembelajaran yang dapat dilakukan untuk mendorong self-regulated learning ini salah satunya dengan model Problem Based Learning (PBL).

Kemampuan peserta didik dalam berpikir dapat dikembangkan dengan penerapan model Problem Based Learning (PBL). PBL atau pembelajaran yang berbasis pada permasalahan merupakan model pengajaran di mana masalah di kehidupan sehari-hari yang kompleks digunakan sebagai instrument untuk memperkenalkan konsep belajar dan prinsip kepada mahasiswa. Selain itu, model ini dapat mendorong perkembangan keterampilan untuk berpikir kritis, kemampuan dalam memecahkan masalah, dan berkomunikasi. Peserta didik nantinya akan berhadapan dengan berbagai masalah kontekstual yang memerlukan kemampuan berpikir dan memecahkan masalah yang baik. Hal ini juga dapat mendorong munculnya kesempatan bagi peserta didik untuk bekerja dalam tim, mengetahui dan mengevaluasi materi penelitian, serta pembelajaran. Masalah yang dipakai dapat bersumber dari surat kabar, majalah, jurnal, buku, buku teks, dan televisi/film. Pemilihan topik permasalahan yang akan dihadapkan kepada mahasiswa ini dapat disesuaikan dengan setiap topik sains yang akan dibahas. Hal ini dilakukan untuk menjaga relevansi antara kasus dengan teori dasar yang akan dibahas lebih lanjut.

Berdasarkan uraian penelitian sebelumnya, dapat dikatakan bahwa Problem Based Learning (PBL) ialah model belajar yang menerapkan konsep dan prinsip ilmu sains termasuk kimia lingkungan, yang juga lebih cocok untuk dipelajari melalui apresiasi skor (Yoon, 2012). Hasil penelitian oleh (Nuswowati et al., 2017) dengan judul "Implementation of problem-based learning with green chemistry vision to improve creative thinking skill and students' creative actions" dengan 
model penelitian berupa mixed method design dengan model eksperimen tertanam melalui pre-test dan post-test pada control group untuk mengetahui pengaruh penerapan Model Pembelajaran Berbasis Masalah (PBL). Hasil penelitian menunjukkan bahwa salah satu bagian dari kegiatan pembelajaran seperti konsultasi dengan dosen dilakukan untuk pelaksanaan tugas, presentasi, dan penulisan ulang dalam bentuk laporan secara lebih detail dari hasil/produk kegiatan kreatif yang telah dilakukan setelah keberlangsungan kegiatan belajar mengajar. Penggunaan model PBL mampu menambah kemampuan berpikir kreatif dan tindakan kreatif mahasiswa (Nuswowati, 2017).

Penelitian lainnya oleh (Suyanta et al., 2019) yang berjudul "The Effect of Problem-Based Learning On Students' Self-Regulated Learning of Chemistry Learning” menggunakan model PBL dengan jenis penelitian berupa quasi-experimental, non-equivalent post-test only group sebagai desain penelitian. Diperoleh hasil yang menunjukkan bahwa adanya perbedaan tingkat kemandirian belajar mahasiswa melalui penerapan pembelajaran berbasis masalah untuk kelas X (topik Elektrolit) dan kelas XI (topik Asam-Basa). Kelas eksperimen baik X maupun XI menunjukkan perolehan hasil yang lebih baik disbanding kelas control tanpa pemberlakuan motode PBL pada kegiatan pembelajaran (Suyanta, 2019).

Penelitian serupa juga dilakukan oleh (Hanipah et al., 2018) yang berjudul "The Effectiveness of Problem Based Learning and Project Based Learning Model to Improve Natural Science Study Outcomes" yang dilakukan dengan model quasi-experimental menggunakan pre-test dan post-test design yang melibatkan dua kelas sebagai kelompok eksperimen. Kelas percobaan pertama, mahasiswa memperoleh perlakuan dengan model belajar yang fokus pada pemecahan masalah dan kelas eksperimen kedua, mahasiswa diberikan model pembelajaran proyek berbasis pembelajaran. Diketahui bahwa: (1) terdapat hasil belajar yang berbeda pada aspek kognitif di antara group based learning dengan project based learning yang diketahui perolehan nilai signifikansinya yaitu 0,001 < 0,05. Sehingga diperoleh kesimpulan bahwa model pembelajaran PBL lebih terbukti dapat meningkatkan hasil pembelajaran terutama pada aspek kognitif mahasiswa dibandingkan model pembelajaran berbasis proyek (Hanipah, 2018).

Berdasarkan referensi serta uraian singkat sebelumnya, maka peneliti berinisiatif untuk melakukan studi literatur untuk mengetahui pengaruh pelaksanaan Problem Based Learning (PBL) pada pembelajaran kimia yang berfokus pada hasil kegiatan belajar mahasiswa pada jenjang perguruan tinggi. 


\section{METODE}

Penelitian ini dilakukan menggunakan analisis pendekatan sistematis melalui sejumlah referensi berupa jurnal yang terbit 10 tahun terakhir, artikel yang relevan termasuk artikel peer review dan artikel teks lengkap Google Scholar dan Science Direct. Tinjauan ini melibatkan berbagai jenjang pendidikan yang menggunakan PBL sebagai model pembelajaran. Analisis literatur sistematis bertujuan untuk mengembangkan tinjauan yang terstruktur dan dapat dikembangkan lebih lanjut. Penelitian ini menggunakan model pendekatan yang digunakan oleh peneliti adalah melalui kajian terhadap penelitian sebelumnya, artikel dan jurnal yang relevan terhadap penelitian. Referensi yang digunana oleh peneliti ialah data sekunder, ialah data yang diperoleh dari hasil studi pustaka (library research). Peneliti akan mengumpulkan sejumlah jurnal dan artikel yang berkaitan dengan model collaborative learning serta Problem Based Learning (PBL) untuk kemudian dipelajari.

Data dalam penelitian ini dikumpulkan peneliti dengan cara mengumpulkan data sekunder (library research) yang mengacu pada kriteria artikel yang terbit 10 tahun terakhir serta berhubungan dengan penerapannya pada kegiatan belajar dan mengajar ilmu kimia. Data kemudian dianalisis oleh peneliti menggunakan analisis deskriptif kualitataif, ialah suatu analisis yang bersifat menjelaskan atau menggambarkan mengenai konsep dasar penerapan model collaborative learning yang dikombinasikan dengan model Problem Based Learning dan mengkaitkan dengan implementasi dalam kegiatan pembelajaran pada pembelajaran kimia.

\section{Hasil dan Pembahasan}

\section{Kegiatan Pembelajaran \& Standar Kompetensi Dasar Pada Pembelajaran Kimia}

Setiap mahasiswa umumnya memiliki cara tersendiri dalam memahami dan memproses informasi yang diperoleh terutama pada kegiatan pembelajaran disarana formal maupun informal. Perbedaan inilah yang disebut dengan gaya belajar yang didefinisikan sebagai preferensi mahasiswa pada suatu proses atau kegiatan dalam proses pembelajaran. Gaya belajar yang khas ini dapat menunjukkan bagaimana setiap individu memproses informasi untuk kemudian dapat dipahami dan di terapkan. Dengan demikian, apabila tenaga pengajar mengerti gaya belajar mahasiswa yang berada di kelasnya tentunya akan memudahkan untuk memilih model pembelajaran yang cocok dengan pola pemahaman yang telah ada (Fatimah, 2014).

Mata kuliah kimia menjadi salah diantara cabang ilmu lainnya yang dianggap sulit untuk dipelajari oleh mahasiswa terutama apabila tenaga pengajar kurang menguasai model pembelajaran yang akan membuat mahasiswa berpartisipasi secara aktif dan tertarik untuk mempelajari subjek ini. Sebagaimana diketahui bahwa untuk mempelajari ilmu kimia memerlukan konsentrasi yang baik 
untuk membuat visualisasi dari materi serta memahami simbol kimia dan reaksi yang terlibat di dalamnya. Pada dasarnya kumpulan formulasi yang dipelajari pada cabang ilmu kimia selalu sama yaitu sesuai dengan konsep dasarnya. Oleh karena itu, tenaga pengajar memiliki peran untuk mempermudah proses penyampaian konsep sehingga dapat lebih cepat dipahami oleh mahasiswa.

Salah satu alasan adanya pencapaian target belajar pada mata kuliah kimia di beberapa mahasiswa masih belum maksimal karena pemakaian model belajar yang tidak cocok dengan konsep maupun teori dari materi yang dipelajari serta paradigma pembelajaran modern. Pada umumnya, tenaga pengajar berperan sebagai transmitter materi dalam proses pembelajaran, sehingga menimbulkan kecenderungan tenaga pengajar untuk bersifat otoriter yang kemudian menciptakan situasi belajar dengan komunikasi satu arah. Cara lain untuk mencapai target dari kegiatan belajar ialah pemilihan cara belajar yang cocok dengan keadaan mahasiswa. Hal ini bertujuan agar mahasiswa dapat menerima dan memahami subjek yang sedang dibahas dengan baik.

Aplikasi model pembelajaran pada kegiatan belajar merupakan hal yang sangat penting. Dengan menggunakan model belajar yang sesuai, mahasiswa akan lebih tertarik dan dapat mendorong kreativitas dan motivasi dalam kegiatan pembelajaran, dapat merubah kebiasan belajar menjadi lebih baik, serta tugas yang diberikan tenaga pengajar saat menyampaikan materi dapat lebih mudah dipahami. Lambat laun, hal ini akan membantu tercapainya objek dan indikator pembelajaran secara merata. Berbagai macam strategi dan pendekatan yang dapat diterapkan tenaga pengajar dalam kegiatan pembelajaran kimia diharapkan dapat memperbaiki kualitas dari kegiatan belajar tersebut (Awalin, 2021). Pemilihan strategi belajar yang dapat menghasilkan perubahan atau konstruktif juga dapat menjadi opsi dalam hal ini.

Implementasi model pembelajaran kolaboratif yang bersifat konstruktif menjadi rekomendasi langkah yang dapat dilakukan oleh tenaga pengajar. Model ini akan membantu pengajar untuk mencapai optimalisasi waktu mengajar yang terbatas. Sebagai poin tambahan, model pembelajaran yang bersifat kolaboratif dapat mengatasi rasa bosan karena dapat menjaga motivasi belajar mahasiswa. Di samping itu, prinsip model belajar yang konstruktif akan memfasilitasi pengajar untuk menyesuaikan konsep ilmu sains yang akan dipelajari dengan konsep yang telah dipahami mahasiswa. Penerapan model ini tentunya juga dapat meinimalisir terjadinya miskonsepsi saat kegiatan belajar mengajar berlangsung. Model yang dapat menghasilkan outcome tersebut dapat berupa model pembelajaran Problem Based Learning atau PBL.

\section{Model Pembelajaran dan Pengaruhnya terhadap Hasil Belajar}

\section{Implementasi Model Pembelajaran Collaborative learning}


Pembelajaran dengan model kolaboratif merupakan proses belajar di mana individu tersusun dalam kelompok kecil yang beranggotakan beberapa orang dan saling membantu antara satu dengan yang lain (Habibi Hidayat, 2019). Pembelajaran kolaboratif yang dimaksud dalam hal ini merujuk pada terciptanya lingkungan di mana mahasiswa dapat belajar, saling membantu dan mengajari materi yang sedang dibahas, serta bekerja sama untuk menyelesaikan tugas kelompok. Dengan demikian, penting bahwa suatu kelompok harus memiliki struktur yang jelas atau bahkan akan lebih baik untuk menyerahkan opsi kepada mahasiswa sendiri untuk memilih dan menyetujui struktur yang akan dipakai.

Lima kriteria yang tercantum di bawah ini, merupakan aspek penting dalam membentuk konsep dasar untuk merefleksikan keberhasilan penerapan model pembelajaran secara kolaboratif, antara lain sebagai berikut (Silalahi, 2020):

1. Saling bergantung dalam hal positif

2. Interaksi promotif

3. Akuntabilitas individu

4. Keterampilan interpersonal dan kelompok kecil, dan

5. Pemrosesan kelompok yang baik

Jika kriteria kualitas pembelajaran kolaboratif diatas dapat tercapai, maka akan terbentuk lingkungan belajar yang cenderung memiliki ciri khas tingkat motivasi mahasiswa yang tinggi dan pengembangan keterampilan non-kognitif. Keterampilan tersebut termasuk kemampuan kerja tim, seperti pengorganisasian, penataan proyek, dan negosiasi suatu solusi setelah terdapat permasalahan dalam kelompok. Model pembelajaran kolaboratif memberikan peluang yang sangat baik untuk pembelajaran dan pengembangan keterampilan sosial yang sangat dibutuhkan saat ini. Penggunaan kegiatan pembelajaran kolaboratif terbukti menghasilkan pencapaian kognitif yang lebih tinggi, pengembangan keterampilan berpikir yang lebih baik, peningkatan kepercayaan diri dan kepuasan mahasiswa serta respon yang lebih baik terhadap materi pembelajaran. Meski demikian, terdapat beberapa kelemahan dari penerapan model ini seperti tenaga pengajar yang sering menghadapi kesulitan saat menyusun aktivitas kolaboratif sebagai contoh memantau perilaku mahasiswa saat mengerjakan tugas, mengelola waktu kerja kelompok, menyediakan materi yang relevan, menetapkan peran tiap individu, dan membangun kerja sama dan perilaku kerja tim. Sebuah penelitian yang dilakukan oleh (Ruys, Van Keer, \& Aelterman, 2012) yang menganalisis persiapan kegiatan kolaboratif tenaga pengajar pada saat pra-jabatan, mengungkapkan kurangnya perhatian tenaga pengajar untuk mengorganisir kerja kolaboratif seperti menentukan norma kelompok dan memfasilitasi kegiatan (Ruys, 2012). Hasil lainnya menunjukkan bahwa sejumlah besar tenaga 
pengajar sering menempatkan mahasiswa dalam kelompok dan membiarkan mereka bekerja sama tanpa mempersiapkan mahasiswa untuk melakukan kegiatan kolaboratif secara produktif.

Kekurangan yang terdapat pada penerapan model collaborative learning terjadi akibat adanya ketidakseimbangan fokus tenaga pengajar terlihat dari penetapan tujuan program belajar. Akibatnya, hal ini akan berpengaruh terhadap munculnya dampak negatif pada kegiatan kolaborasi antar mahasiswa pada kegiatan pembelajaran. Mahasiswa hanya bertujuan untuk mencapai pembelajaran akademik individu dan mengabaikan pentingnya interaksi sosial. Ketika tenaga pengajar dan mahasiswa tidak terlalu memperhatikan aspek kolaboratif, maka terdapat kemungkinan mengalami sejumlah hambatan untuk efektivitas penerapan model ini. Di sisi lain, kelebihan yag dihasilkan dari model CL apabila berhasil diterapkan dengan efektif diantaranya meningkatkan kemampuan kognitif serta sosialisasi mahasiwa, meningkatkan motivasi belajar; meningkatkan pencapaian akademik melalui kerja sama tim yang baik, meningkatkan kemampuan kolaboratif atau kerja sama, meningkatkan kemampuan komunikasi, meningkatkan etika dalam bekerja sama dalam tim, serta meningkatkan kemampuan mahasiswa dalam memimpin diskusi kelompok (Le, 2017).

Contoh penerapan model tersebut pada kegiatan belajar di cabang ilmu kimia, seperti komponen kelas latihan, kerja praktek, dan kursus laboratorium yang dianggap sebagai elemen penting dari pengajaran kimia (Kaendler, 2016). Kegiatan praktis ini berfokus pada bagaimana pengetahuan teoritis dapat digunakan untuk memecahkan masalah teoritis maupun praktis. Idealnya, tingkat pemahaman yang lebih baik mulai dari kemampuan untuk menggunakan konsep dan rumus yang diajarkan dalam proses pemecahan masalah "sederhana", hingga kemampuan untuk menggunakan pengetahuan dasar yang lebih luas untuk memecahkan masalah "kompleks" yang memerlukan kombinasi pengetahuan dari berbagai bidang, dapat dikembangkan melalui model ini (Strijbos, 2014). Pada akhirnya, mahasiswa secara naluriah akan terdorong untuk mencapai posisi di mana mereka mampu secara kreatif dan mandiri mengembangkan atau menemukan ide dan strategi ilmiah untuk dipakai namun tetap berdasarkan penyelidikan eksperimental. Salah satu contoh model collaborative learning yang dapat diterapkan untuk mencapai target dan output proses belajar mengajar seperti yang disebutkan diatas adalah Model Belajar Problem Based Learning (PBL) (Chiriac, 2012).

\section{Karakteristik Model Belajar Problem Based Learning (PBL)}

Kegiatan belajar mengajar yang efektif akan membuat situasi belajar menjadi kondusif. Beberapa penelitian sebelumnya menunjukkan bahwa model mengajar yang efektif adalah salah satu faktor yang memiliki peran yang mempengaruhi pencapaian dalam kegiatan belajar (Missildine, 2013). Disamping itu, keberagaman cara dan strategi mengajar yang dipakai dapat membantu pupil 
mata untuk lebih fokus dalam mencerna dan memproses kegiatan pemecahan masalah, memahami teori, menggunakan pengetahuan baru untuk memperoleh solusi dari permasalahan yang diterima (Schultz, 2012). Jika tenaga pengajar dapat menyampaikan materi dengan efektif, maka kualitas kegiatan belajar akan meningkat disamping partisipasi mahasiswa yang akan lebih aktif. PBL ialah model yang dapat digunakan untuk menstimulus terciptanya situasi belajar yang efektif berdasarkan pada konsep konstruktif sosial (Allen, 2011).

Problem Based Learning (PBL) merupakan model yang diperkenalkan di McMaster University, Canada pada tahun 1969. Pada perkembangan selanjutnya, model ini tersebar dan digunakan secara luas di berbagai disiplin ilmu seperti manajemen, mesin, agrikultur, dan hukum. PBL dapat dikaitkan dengan pendekatan pendidikan yang berfokus pada pengambilan masalah sebagai titik awal dalam proses pembelajaran, yang didasarkan pada perspektif seperti kegiatan belajar yang berpusat pada mahasiswa, pembelajaran berbasis pengalaman, pembelajaran berbasis aktivitas, pembelajaran interdisipliner, fokus pada praktik, dan pembelajaran kelompok kolaboratif (Nurliana, 2015). PBL memiliki tujuan untuk meningkatkan dan membuat hasil belajar menjadi optimal karena terpusat pada mahasiswa, bersifat kolaboratif, kontekstual, terintegrasi, mandiri, dan dapat memperkenalkan kegiatan pembelajaran yang lebih reflektif. Penggunaan PBL dapat dipengaruhi oleh lingkungan struktural dan pedagogis di mana hal itu terjadi karena melibatkan faktor-faktor seperti materi pelajaran, mahasiswa, tenaga pengajar dan organisasi.

Sebagai salah satu model pembelajaran, PBL mencakup komponen-komponen berikut struktur kurikulum program, pembelajaran berbasis kelompok dan evaluasi (Barbosa, 2018). Pembelajaran berbasis kelompok tidak hanya memberikan fasilatas untuk ilmu pengetahuan, namun juga komponen lainnya seperti keterampilan dalam berkomunikasi, kerja sama dalam kelompok, pemecahan masalah, tanggung jawab mandiri untuk belajar, berbagi informasi, dan sikap menghormati orang lain. Oleh karena itu, PBL dapat dianggap sebagai model belajar pada kelompok kecil yang menggabungkan perolehan pengetahuan dengan pengembangan keterampilan dan sikap dasar (Stanislaus, 2017).

Untuk membantu proses pemahaman terhadap model PBL, konsep dasar model ini secara luas terbagi menjadi beberapa bagian sebagai berikut:

1. Karakteristik dalam model PBL meliputi pengorganisasian kurikulum dan kelas terpadu untuk penyelesaian masalah, di samping penekanan pada keterampilan kognitif;

2. Kondisi tertentu memfasilitasi PBL, seperti kelompok kecil, instruksi tutorial dan pembelajaran aktif; dan

3. PBL menekankan pada hasil, seperti pengembangan keterampilan dan motivasi untuk 
terus menjadi long life learner.

Tujuan utama dalam model PBL adalah untuk menghasilkan diskusi yang produktif. Untuk mencapai tujuan akhir ini, masalah yang dipelajari harus memiliki karakteristik diantaranya harus sederhana dan objektif untuk menghindari kebingungan dalam mengidentifikasi tujuan utama, dapat memotivasi mahasiswa, mencakup deskripsi netral dari kasus tersebut, mampu menjelaskan informasi yang diperlukan untuk penyelesaian masalah, tidak boleh mencakup prosedur untuk penyelesaiannya, harus memungkinkan mahasiswa untuk membuat keputusan yang unik, harus fokus pada beberapa topik pembelajaran, mengandung unsur-unsur tentang pengetahuan dimiliki mahasiswa sebelumnya, harus menetapkan batas sekitar 16 jam untuk kegiatan belajar mandiri (Yuanita, 2019).

Terdapat tiga kunci dalam model PBL yaitu permasalahan pada kehidupan sehari-hari, proses belajar berbasis kelompok, dan kelompok kontrol mahasiswa. Model ini juga disebut sebagai suatu sistem belajar mengajar yang dibangun secara simultan antara strategi pemecahan masalah dengan pengetahuan yang berfokus pada isu-isu atau masalah yang menjadi titik awal dari proses pembelajaran. Dengan demikian, model ini telah membantu meningkatkan kemampuan mahasiswa dalam hal pembelajaran secara mandiri, berpikir kritis (Osman, 2013), keterampilan dalam kerja sama tim, memiliki kualitas kepemimpinan dan pembelajaran kolaboratif (Ansari, 2015). Komponen utama dalam penerapan model ini pada kegiatan pembelajaran antara lain 1) mahasiswa akan diberi tanggung jawab dalam merencanakan pembelajaran mereka sendiri, 2) masalah merupakan kunci utama dalam model ini, 3) tenaga pengajar bertindak sebagai fasilitator, 4) mahasiswa diharuskan melakukan refleksi, 5) mahasiswa harus belajar sesuatu dari berbagai sumber yang relevan dengan topik dalam proses memecahkan masalah (Zakaria, 2019).

Terdapat beberapa model penilaian dalam penerapan PBL, di antaranya presentasi kelompok atau individu, penilaian ganda antara anggota kelompok dan kelompok, laporan individu tentang kasus yang dipelajari, pengembangan portofolio (menyajikan masalah, mengumpulkan informasi dan mengajukan hipotesis, dan menulis laporan temuan), penilaian diri, penilaian teman sekelas, penilaian kelompok terbuka, refleksi online yang ditulis mingguan dan dinilai pada akhir semester, penilaian oleh tutor/fasilitator, penilaian tertulis dan penilaian di mana anggota kelompok bekerja sama untuk menyerahkan laporan tertulis bersama yang berisi pengamatan dan komentar mereka (Nursa'ban, 2019).

\section{Keuntungan dan Kekurangan Model PBL}

Model PBL menjadi strategi pada kegiatan belajar secara aktif yang menyediakan kesempatan bagi mahasiswa untuk memimpin proses belajarnya, memberikan kesempatan kepada mahasiswa 
untuk bekerja secara kolaboratif dan mengembangkan kemampuan untuk belajar di bawah arahan diri sendiri, memecahkan masalah melalui proses investigasi, menganalisis data, dan mengusulkan solusi (Barbosa, 2018). Model pembelajaran berbasis permasalahan atau PBL berhubungan dengan kecerdasan individu dalam suatu sekelompok atau lingkungan untuk memecahkan masalah yang relevan dan kontekstual. Permasalahan ini digunakan dalam pembelajaran berbasis proyek sebagai langkah awal dalam mengumpulkan dan mengintegrasikan pengetahuan baru berdasarkan pengalaman dalam kegiatan nyata. Model inovatif dalam proses pembelajaran dapat membuat mahasiswa berpartisipasi lebih aktif dalam kegiatan pembelajaran (Latipah, 2021). Hasil penelitian dari Haryono menunjukkan bahwa tenaga pengajar yang berkualitas mampu menerapkan berbagai inovasi dalam kegiatan belajar sehingga dapat mempengaruhi hasil belajar mahasiswa (Haryono, 2017). Beberapa kelebihan dari penerapan model PBL diantaranya, mahasiswa menjadi terbiasa dalam kegiatan pemecahan masalah dari tenaga pengajar, yang kemudian akan membuat mahasiswa lebih mandiri (Abanikannda, 2016). Kedua, penerapan model PBL membuat mahasiswa dapat berpikir kritis (Tarigan, 2017). serta terbukti meningkatkan aktivitas belajar mahasiswa (Nurliana, 2015).

Penggunaan model PBL juga dapat menjadikan mahasiswa memiliki pengalaman lebih dalam mengumpulkan, mengatur, dan menyimpan informasi dalam memori yang selanjutnya dapat digunakan untuk penggunaan di kemudian hari. Mahasiswa juga berhadapan dengan masalah yang kompleks dan realistis. Partisipasi aktif mahasiswa yang muncul dalam kelompok kecil membutuhkan keterampilan interpersonal yang baik, seperti mendengarkan, bernegosiasi, berkompromi, mendidik teman sebaya, memberi dan menerima kritik, dan memberikan motivasi orang lain (Abanikannda, 2016)

Kelemahan penerapan model PBL dalam penelitian berada pada tahap pertama ialah pemberian masalah pada mahasiswa, sebagian mahasiswa kurang mampu menghubungkan masalah dalam kehidupan sehari-hari, sehingga kurang percaya diri dalam menyelesaikan masalah, pada ketiga tahap yaitu membantu investigasi mandiri dan kelompok, masih banyak mahasiswa yang bingung dalam melaksanakan praktikum karena tidak terbiasa menggunakan alat dan bahan praktikum serta tidak memahami prosedur kerja yang akan dilakukan sehingga menyebabkan kelas menjadi kurang kondusif dan terkendali. Pada tahap kelima ialah mempresentasikan dan mengevaluasi proses penyelesaian masalah, peneliti kekurangan waktu sehingga tiap kelompok melakukan presentasi hasil diskusi di depan kelas karena memakan banyak waktu dalam fase ketiga, yaitu dalam proses penyelidikan masalah (Batlolona, 2020). 
Kelemahan lainnya dari model PBL yaitu penerapan kerja sama dalam tim yang menjadi faktor pendorong dan faktor pembatas. Hal ini merujuk pada kompleksitas hubungan mahasiswa dalam konteks pendidikan, yang melibatkan aspek perilaku dan sosial dan harus dipertimbangkan oleh tenaga pengajar yang bertanggung jawab pada penerapan strategi di kelas. Faktor-faktor seperti kepasifan, kurangnya komitmen dari beberapa anggota kelompok dan kesulitan mencapai konsensus tentang solusi yang diusulkan dapat menghambat kemampuan kelompok untuk memecahkan masalah, dan menjadi tugas tenaga pengajar untuk meminimalisir kemungkinan terjadinya hal ini (Syifaiyah, 2018).

Selain kerja tim, faktor waktu juga menjadi tantangan tersendiri dalam penerapan model ini untuk kegiatan belajar. Dalam kurikulum yang berfokus pada materi pembelajaran, di mana tenaga pengajar berperan sebagai figur utama dan penyampai materi, akan lebih sulit untuk memperkenalkan strategi yang menunjuk mahasiswa untuk berperan aktif dalam pembelajaran. Terlebih dengan kondisi di mana budaya self-directed learning yang belum dimasukkan ke dalam perilaku pada mayoritas mahasiswa pada pertenaga pengajaran tinggi. Dengan demikian, salah satu kontribusi PBL adalah mendorong mahasiswa untuk menjadi akrab dengan proses pembelajaran yang lebih berbasis pengalaman melalui tindakan, dengan penekanan pada pengembangan rasa pengembangan diri (Komariah, 2019).

\section{Hasil Penerapan Model Belajar Problem Based Learning (PBL)}

Model PBL adalah model pembelajaran yang fokus terhadap kerangka teori konstruktivisme. Pada model pembelajaran ini, fokus pembelajaran terletak pada permasalahan yang dipilih sehingga mahasiswa tidak hanya mempelajari konsep-konsep yang berkaitan dengan masalah tetapi juga model ilmiah untuk memecahkan masalah tersebut. Oleh karena itu, mahasiswa tidak hanya harus memahami konsep-konsep yang relevan dengan masalah yang menjadi pusat perhatian tetapi juga memperoleh pembelajaran yang berkaitan dengan keterampilan dalam menerapkan model ilmiah untuk pemecahan masalah dan pengembangan pola berpikir kritis (Stanislaus, 2017). Berdasarkan hasil analisis dari penelitian yang dilakukan oleh Hanipah diketahui bahwa pembelajaran yang menggunakan model berbasis masalah lebih efektif untuk memperbaiki kualitas hasil belajar mahasiswa. Hal ini dapat diamati dari adanya perbedaan rata-rata nilai hasil belajar setelah penerapan model ini (Hanipah, 2018)

Hasil ini memberikan gambaran bahwa model PBL mampu meningkatkan keaktifan mahasiswa dapat kegiatan belajar yang berhubungan positif terhadap hasil belajar. Hubungan yang dihasilkan dari partisipasi aktif mahasiswa ini dapat dilihat dari penggunaan model ini dalam pembelajaran sains. Model pembelajaran berbasis masalah dirancang untuk memberikan beberapa masalah dan menuntut 
mahasiswa untuk memperoleh pengetahuan esensial, kemudian mahasiswa dapat memecahkan masalah, mereka memiliki model pembelajaran sendiri dan dapat mengeksplorasi keterampilannya dalam kerja tim. Masalah yang diberikan dalam model pembelajaran ini memiliki konteks yang sesuai dengan kondisi nyata sehari-hari. Apabila mahasiswa lebih dekat dengan kondisi nyata maka akan memberikan pengaruh yang lebih baik terhadap peningkatan keterampilan mahasiswa. Hal ini menunjukkan bahwa melalui penerapan model belajar berbasis permasalahan dapat meningkatkan hasil kegiatan belajar kognitif mahasiswa (Hanipah, 2018). Selain itu, kegiatan belajar dengan model PBL dalam ilmu sains khususnya pada cabang ilmu kimia dapat membuat mahasiswa terlibat penuh untuk menemukan solusi dari suatu masalah. Konsep inilah yang kemudian dapat meningkatkan hasil belajar secara efektif. Hasil penelitian menunjukkan bahwa penerapan model berbasis masalah efektif digunakan dalam pembelajaran karena meningkatkan sikap peduli mahasiswa dan hasil belajar pada subjek kimia lebih baik dibandingkan penggunaan buku pada model konvensional pada umumnya. Penggunaan model berbasis proyek dapat membuat mahasiswa tidak hanya mempelajari pengetahuan pada materi yang disampaikan tetapi juga soft skill. Terdapat peningkatan keterampilan kritis, berpikir kreatif, dan keterampilan generik mahasiswa dengan pembelajaran berbasis proyek. Penerapan model pembelajaran berbasis masalah dapat memberikan pengaruh yang lebih baik dalam meningkatkan hasil belajar dan keterampilan mahasiswa (Indirawati, 2016).

Hasil penelitian lainnya juga menunjukkan bahwa minat terhadap materi yang diberikan meningkat sehingga sangat baik untuk memotivasi mahasiswa dalam pemahaman materi. Pada awal pembelajaran, mahasiswa dapat mengalami kesulitan dalam melaksanakan praktikum pada subjek yang sedang dipelajari. Namun setelah terlibat dalam proses pembelajaran, mahasiswa akan merasakan kemudahan dalam mengimplementasikan komponen-komponen tersebut. Selain itu, pembelajaran menggunakan model PBL juga terbukti mampu membuat mahasiswa dapat mengerjakan tes uji pemahaman dengan hasil yang lebih baik dibanding model lainnya. Secara umum mahasiswa memberikan respon yang sangat positif terhadap pembelajaran kimia dengan model problem based learning (Syifaiyah, 2018).

\section{Kombinasi Collaborative Learning dengan Model Problem Based Learning dalam Proses Pembelajaran Ilmu Kimia}

Pendekatan menggunakan CL dengan model PBL merupakan cara yang efektif untuk mengembangkan kemampuan pada abad ke-21 dengan mendorong terbentuknya pemikiran kritis serta pemecahan masalah, komunikasi interpersonal, literasi informasi dan media, kerjasama, kepemimpinan dan kerja tim, inovasi, serta kreativitas. Hasil penelitian menunjukkan bahwa dari pendekatan PBL baik pada tenaga pengajar maupun mahasiswa telah menunjukkan bahwa model ini 
dapat meningkatkan kemampuan pemecahan masalah dan kinerja akademik dan mempengaruhi persepsi positif dari profesi belajar.

Konsep PBL menggambarkan kolaborasi antara dua atau lebih tenaga pengajar dalam suatu kegiatan pembelajaran ketika berada dalam proses perencanaan, pelaksanaan, dan/atau evaluasi yang melibatkan pertukaran keahlian pelatihan dan percakapan reflektif dengan mahasiswa. Telah terbukti bahwa pendekatan PBL memberikan pengalaman belajar yang bervariasi dan berharga bagi tenaga pengajar yang belum berpengalaman dan mendukung pengembangan profesional sehingga akan memudahkan proses penyampaian ilmu kepada mahasiswa. Model CL dengan PBL memungkinkan dosen dan mahasiswa untuk berbagi proses informasi. Topik khusus dapat dibahas dari perspektif yang berbeda atau dengan pendekatan pedagogis yang melibatkan kerja tim. Tenaga pengajar dan mahasiswa dapat mengambil manfaat dari teknik PBL melalui dukungan profesional dan emosional, peningkatan pembelajaran profesional, dan pengembangan pribadi.

Oleh karena itu, untuk menerapkan model ini secara maksimal maka perlu memberikan mahasiswa kesempatan untuk mengerjakan masalah dengan tingkat kesulitan yang semakin tinggi, terbiasa terlibat dalam masalah secara terus-menerus, menemukan jawaban yang valid sesuai dengan konsep dasar yang diajarkan. Hasil ini akan tercapai apabila penerapan model ini dapat berlangsung secara efektif dan terdapat respon positif setelah tenaga pengajar berhasil mengarahkan mahasiswa dengan baik.

\section{KESIMPULAN}

Berdasarkan uraian sebelumnya, dapat diperoleh kesimpulan bahwa penggunaan metode PBL dalam kegiatan pembelajaran cabang ilmu kimia terutama apabila dibandingkan dengan pembelajaran konvensional menunjukkan bahwa pendekatan dengan metode PBL lebih efektif dalam hal prestasi belajar ilmu kimia. Metode CL yang dikombinasikan dengan PBL memungkinkan tenaga pengajar dan mahasiswa untuk berbagi proses informasi dengan lebih efektif dan efisien. Topik khusus dapat dibahas dari perspektif yang berbeda atau dengan pendekatan pedagogis yang melibatkan kerja tim. Tenaga pengajar dan mahasiswa dapat mengambil manfaat dari model PBL melalui dukungan profesional dan emosional, peningkatan pembelajaran profesional dan pengembangan pribadi. Penggunaan PBL sebagai strategi pengajaran aktif menunjukkan potensi penggunaan untuk kegiatan belajar melalui integrasi dimensi kognitif, perilaku dan sosial mahasiswa, mendorong integrasi yang lebih dekat dengan konteks aktivitas profesional. Oleh karena itu, penggunaan metode PBL dapat meningkat prestasi akademik dan pemhaman mahasiswa terkait pembelajaran kimia. Sedangkan peran tenaga pengajar pada metode ini yaitu dapat membantu mahasiswa untuk memperoleh 
keterampilan yang dibutuhkan untuk digunakan dalam kehidupan sehari-hari seperti kerjasama, analisis, penelitian komunikasi, sintesis dan keterampilan pemecahan masalah. Dengan demikian, tenaga pengajar hendaknya dapat mempertimbangkan pendekatan model CL dengan PBL. Namun pada umumnya mahasiswa yang terbiasa dengan perkuliahan menggunakan metode konvensional cenderung tidak nyaman saat menggunakan pendekatan PBL untuk pertama kalinya sehingga memerlukan waktu untuk beradaptasi.

\section{DAFTAR PUSTAKA}

Abanikanda, 2016. Influence of Problem-Based Learning in Chemistry on Academic Achievement of High School Students In Osun State, Nigeria. International Journal of Education Learning and Development, 3(4), pp. 55-63.

Allen, D. E. D. R. S. \&. B. S. A., 2011. Problem-Based Learning. Volume 128, pp. 21-29.

Ansari, M. T. R. S. A. B. V. B. S. F. \&. A. M. S., 2015. Problem Based Learning (PBL): A Novel and Effective Tool of Teaching and Learning. Indian Journal of Pharmaceutical Education and Researc, 4(49), pp. 258-265.

Awalin, N. A., 2021. Integrative Science Education and Teaching Activity Journal The Implementation of Problem Based Learning Model With STEM ( Science , Technology, Engineering, Mathematics ) Approach to Train St udents' Science Process Skills of XI Grade. 1(2), pp. 1-14.

Barbosa, A. S. D. C. A. A. K. D. R. D. G. I. F. \&. V. F., 2018. Problem-based learning A proposal for structuring PBL and its implications for learning among students in an undergraduate management degree program. 2(25), pp. 160-177.

Batlolona, J. R. S. S. \&. D. M., 2020. Influence of Problem Based Learning Model on Student Mental Models. Jurnal Pendidikan Fisika Indonesia, 1(16), pp. 14-23.

Chiriac, E. H. \&. G. K., 2012. Teachers and Teaching: Theory and Practice Teachers' Leadership and Students' Experience of Group Work. 3(18), pp. 37-41.

Fatimah, F. \&. W. A., 2014. Pengembangan Science Comic Berbasis Problem Based Learning Sebagai Media Pembelajaran Pada Tema Bunyi dan Pendengaran Untuk Siswa SMP. JurnalPendidikan IPA Indonesia, 2(3), pp. 146-153.

Habibi Hidayat, R. S. \&. B. A., 2019. Implementation of Cooperative Learning Model by Greeting and Question Technique to Improve the Learning Outcomes and Activities Students in SMA 1 Bengkulu. International Journal of Chemistry Education Research, 2(3), pp. 40-43. 
Handayani, P., Angestanto, A. \& Marukan, 2013. Pengaruh Pembelajaran Berbasis Masalah dengan Asesmen Kinerja Terhadap Kemampuan Pemecahan Masalah. Unnes Journal of Mathematichs Education, 2(1), pp. 70-76.

Hanipah, S. F. T. S. \&. R. A. R., 2018. The Effectiveness of Problem Based Learning and Project Based Learning Model to Improve Natural Science Study Outcomes. Innovative Journal of Curriculum and Educational Technology, 1(7), pp. 1-6.

Haryono, H. \&. Y. A., 2017. Kepemimpinan Kepala Sekolah, Supervisi Akademik, dan Motivasi Kerja dalam Meningkatkan Kinerja Guru. Educational Management, 1(6), pp. 26-33.

Indirawati, A. S. S. M. \&. S. K. I., 2016. Pembelajaran Berbasis Masalah dengan Bahan Ajar Berorientasi Sumber Daya Peraiaran Terhadap Karakter Peduli Lingkungan dan Hasil Belajar IPA. Journal of Primary Education, 2(5), pp. 88-96.

Kaendler, C. \&. S. H., 2016. Monitoring Student Interaction during Collaborative Learning: Design and Evaluation of a Training Program for Pre-Service Teachers. Psychology Learning \& Teaching, 0(0), pp. 1-21.

Kalenda, J. \&. V. S., 2016. Self-regulated Learning in Students of Helping Professions. ProcediaSocial and Behavioral Sciences, Volume 217, p. 282-292.

Komariah, K. S. H. \&. W., 2019. Problem-Based Learning: Implementasi dan Urgensinya Bagi Peningkatan Kualitas Pembelajaran. Jurnal Pendidikan, 2(3), pp. 207-219.

Latipah, R. A. I. R. S. \&. S. U. N., 2021. Problem Based Module Development as Preparation for Selection of Science Olympicers in Biology Field. Journal of Innovative Science Education, 37(10), pp. 325-338.

Le, H. J. J. \&. W., 2017. Collaborative learning practices : teacher and student perceived obstacles to effective student collaboration Collaborative learning practices. Cambridge Journal of EduCation, 1(48), pp. 103-122.

Missildine, K. F. R. S. L. \&. G. K., 2013. Flipping the classroom to improve student performance and satisfaction. Journal of Nursing Education, 10(52), pp. 597-599.

Nurliana, \&. J. R., 2015. Pengaruh Model Pembelajaran Berbasis Masalah Terhadap Hasil BelajarSiswa Pada Materi Pokok Gerak Lurus Kelas X Semester I SMA Negeri 11 Medan T.A. 2014/2015. Jurnal Inpafi, 1(3), pp. 139-146. 
Nursa'ban, E. M. M. \&. Y. S., 2019. Improving student learning outcomes in science subjects through the implementation of PBL-based module. Jurnal Pendidikan Biologi Indonesia, 2(5), pp. 269276.

Nuswowati, M. S. E. R. \&. K. S., 2017. Implementation of problem-based learning with green chemistry vision to improve creative thinking skill and students' creative actions. Jurnal Pendidikan IPA Indonesia, 2(6), pp. 221-228.

Osman, M. H., 2013. Ready Or Not: Students With Self-Directed Learning?. Journal of Engineering Science and Technology, pp. 84-90.

Ruys, I. K. H. V. \&. A. A., 2012. Examininh Pre-service Teacher Competence in Lesson Planning Pertaining to Collaborative Learning. Journal of Curriculum Studies, 3(44), pp. 349-379.

Schultz, D. D. S. R. S. C. \&. W. J., 2012. Effects of the Flipped Classroom Model on Student Performance for Advanced Placement High School Chemistry Students. Journal of Chemical Educatio, 9(91), pp. 1334-1339.

Silalahi, T. F. \&. H. A. F., 2020. The Application of Cooperative Learning Model during Online Learning in the Pandemic Period. Budapest International Research and Critics InstituteJournal, 3(3), pp. 1683-1691.

Stanislaus, S. \&. W. G. P., 2017. Peningkatan Profesionalisme Guru melalui Pelatihan Inovasi Pembelajaran: Program Rintisan bagi Guru di Kabupaten Semarang. Lembaran Ilmu Kependidikan, 2(46), pp. 75-80.

Strijbos, J., 2014. Assessment of (Computer-Supported) Collaborative Learning. IEEE Transactions on Learning Technologies, 1(4), pp. 59-73.

Susilowati, \&. H. P. W., 2013. Pengembangan Petunjuk Praktikum Pendidikan IPA Berbasis Pedagogy Content Knowledge Mahasiswa Calon Guru. Jurnal Kependidikan, 2(23), p. 144153.

Suyanta, L. E. W. F. N. F. \&. R. I., 2019. The Effect of Problem-Based Learning on Students' SelfRegulated Learning of Chemistry Learning. Jurnal Kependidikan, 2(3), pp. 187-193.

Syifaiyah, R. T. T. \&. E. E. t., 2018. Development of Chemistry Instruction Material Using Problem Based Learning Model for Increasing the Student of Senior High School Learning Achievemen. JPPS (Jurnal Penelitian Pendidikan Sains), 2(7), p. 1479. 
Tarigan, R., 2017. The Effect of Problem Based Learning Model for Student Learning Outcomes on Materials Temperature of Heat and Heat Transfer in Class X Semester II SMA N 16 Medan. Journal of Research \& Method in Education, 5(7), pp. 32-37.

Yoon, H., 2012. The Efficacy of Problem-based Learning in an Analytical Laboratory Course for Preservice Chemistry Teachers. International Journal of Science Education, 1(36), pp. 1-24.

Yuanita, L. I. M. \&. P. B. K., 2019. Innovative Chemistry Learning Model: Improving The Critical Thinking Skill and Self-Efficacy of Pre-Service. Journal of Technology and Science Education, 1(9), pp. 59-76.

Zakaria, M. I. M. S. M. \&. K. F. A., 2019. Systematic Review of Problem Based Learning in Education. Creative Education, 12(10), pp. 2671-2688. 